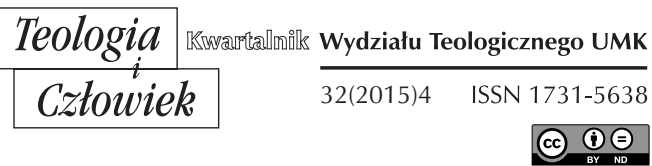

KS. JANUSZ GRĘŹLIKOWSKI*

WŁOCŁAWEK-WARSZAWA

\title{
ZDRADA TAJEMNICY SPOWIEDZI W OBOWIĄZUJĄCYM PRAWODAWSTWIE KOŚCIELNYM
}

DOI: http://dx.doi.org/10.12775/TiCz.2015.053

Sakrament pokuty i pojednania jest istotnym elementem Bożej ekonomii zbawienia, doświadczeniem Bożego miłosierdzia, a tym samym istotnym punktem programu uświęcania i zbawienia człowieka realizowanego przez Kościół. Usilnie zwraca na to uwagę papież Franciszek w swoim liście Misericordiae vultus (Oblicze miłosierdzia), który zawiera rozporządzenia dotyczące sakramentu pokuty i pojednania oraz odpustów w jubileuszowym Roku Miłosierdzia, który decyzją Ojca Świętego będzie obchodzony w Kościele od 8 grudnia 2015 do 20 listopada 2016 r. Wierny grzesznik nie ma innej możliwości pojednania się z Bogiem i Kościołem jak tylko przez uznanie swojej winy, uświadomienie sobie skutku zła, którego jest sprawcą, szczery żal i postanowienie poprawy. Indywidualna i całkowita spowiedź oraz rozgrzeszenie to jedyny zwyczajny sposób

* Ks. dr hab. Janusz Gręźlikowski - prezbiter diecezji włocławskiej, doktor habilitowany nauk prawnych w zakresie prawa kanonicznego, profesor Wyższego Seminarium Duchownego we Włocławku, oficjał Sądu Biskupiego, profesor nadzwyczajny i kierownik Katedry Historii Kościelnego Prawa Polskiego na Wydziale Prawa Kanonicznego UKSW w Warszawie. 
pojednania się wiernego, który jest świadom grzechu ciężkiego, z Bogiem i Kościołem ${ }^{1}$. Sakramentalną posługę pokuty Kościół spełnia przez biskupów i prezbiterów. Udzielają oni wiernym odpuszczenia grzechów w imieniu Chrystusa i mocą Ducha Świętego. Władzę przebaczania grzechów w imię Boga Chrystus przekazał Apostołom², to pełnomocnictwo przeszło na biskupów i kapłanów. Ci ostatni, wykonując sakramentalną posługę pokuty, działają w łączności z biskupem i uczestniczą w jego władzy i urzędzie ${ }^{3}$. Sprawowanie sakramentu pokuty i spowiadanie wiernych jest obowiązkiem każdego kapłana, który „występuje w tym sakramencie w charakterze sędziego i równocześnie lekarza, został przez Boga ustanowiony szafarzem boskiej sprawiedliwości i zarazem miłosierdzia i ma przyczyniać się do oddania czci Bogu i zbawienia dusz"4.

Biorąc pod uwagę świętość, bardzo wrażliwy i delikatny charakter oraz wielkość tej posługi sakramentalnej oraz szacunek należny wiernemu, dla którego sakrament pokuty i pojednania jest jednym z elementów tworzących drogę do osiągnięcia zbawienia, każdy kapłan, który sprawuje sakrament pokuty i pojednania, zobowiązany jest do roztropności, wrażliwości i delikatności, a jednocześnie pod bardzo surowymi karami do zachowania absolutnej tajemnicy odnośnie do grzechów wyznawanych przez penitenta. Stosowne regulacje prawa kanonicznego zabraniają spowiednikowi słowem, znakiem lub w jakikolwiek inny sposób i z żadnego powodu wyjawić czy też zdradzić to, co zostało mu powierzone w akcie spowiedzi ${ }^{5}$. Nie może on również wykorzystywać wiadomości o życiu penitentów, jakie uzyskał w czasie spowiedzi. Tajemnica ta, która nie dopuszcza żadnych wyjątków, nazywa się „pieczęcią sakramentalną”, ponieważ to, co penitent wyznał spowiednikowi, zostaje „zapieczętowane przez sakrament" ${ }^{\circ}$, a tajemnica sakramentalna jest nienaruszalna.

Prawodawstwo kościelne wyróżnia dwie formy zdrady tajemnicy sakramentalnej spowiedzi: zdradę bezpośrednią (wprost) i pośrednią

${ }^{1}$ Por. kan. 960 KPK; zob. L. Gerosa, Prawo Kościoła, Poznań 1999, s. 212-213.

2 Zob. Mt 16,19; Mt 18,18; J 20,22-23.

3 Por. T. Pawluk, Prawo kanoniczne według Kodeksu Jana Pawła II, t. 2: Lud Boży jego nauczanie i uświęcenie, Olsztyn 1986, s. 406-407.

${ }^{4}$ Por. kan. 978 i 986 KPK.

5 Por. kan. 983 \& 1 KPK.

${ }^{6}$ Zob. Katechizm Kościoła Katolickiego, Poznań 1994, nr 1467 (cyt. dalej: KKK). 
(uboczną). W zależności od rodzaju niedochowania tajemnicy prawo kodeksowe nakłada na spowiedników stosowne sankcje karne, które zostały dodatkowo określone i uszczegółowione przez Kongregację Nauki Wiary w normach De gravioribus delictis z 2001 r. $^{7}$ i normach De delictis reservatis z 2010 r. $^{8}$ Warto zatem $\mathrm{w}$ oparciu na normach kodeksowych i w świetle wspomnianych ostatnio uregulowań Kongregacji Nauki Wiary ukazać najważniejsze kwestie związane z zagadnieniem zdrady tajemnicy spowiedzi, a szczególnie - co podejmuje niniejsze opracowanie - odpowiedzieć na pytania: czym jest oraz na czym polega zasada nienaruszalności tajemnicy spowiedzi i czy prawo kościelne przewiduje wyjątki od tej zasady? Jaką ochronę ustawodawstwo kościelne gwarantuje tajemnicy spowiedzi? Jaka jest różnica pomiędzy wspomnianymi dwiema formami naruszenia tajemnicy spowiedzi i jakie są i jak zmieniły się przepisy regulujące kwestię karania za popełnione naruszenie tej tajemnicy?

\section{CZYM JEST I NA CZYM POLEGA TAJEMNICA SAKRAMENTU POKUTY I POJEDNANIA}

Jak należy rozumieć tajemnicę, o której tu mowa? Najpierw należy powiedzieć, czym jest prawda i jak przy zaleceniach bycia prawdomównym, a prawdomówność jest cnotą, należy rozumieć dyskrecję i tajemnicę w Kościele. Katechizm Kościoła Katolickiego stwierdza, że ludzie, którzy wierzą w Chrystusa, mają obowiązek tworzenia wspólnoty na fundamentach prawdy i miłości, a przykazanie Boże brzmiące „nie mów fałszywego świadectwa przeciw bliźniemu swemu” zobowiązuje do życia między ludźmi w prawdzie i z szacunkiem do godności ludzkiej'. Należy jednak pamiętać, że prawo do mówienia prawdy nie jest absolutne, „każdy powinien dostosować swoje życie do ewangelicznej zasady miłości brater-

7 Joannes Paulus II, Litterae Apostolacie motu proprio datae quibus Normae de gravioribus delictis Congregationi pro Doctrina Fidei reservatis promulgantur, Sacramentorum sanctitatis tutela (30.04.2001), AAS 93(2001), s. 737-739.

${ }^{8}$ Congregatio pro Doctrina Fidei, Normae de delictis Congregationi pro Doctrina Ficei reservatis seu Normae de delictis contra Fidem necnon de gravioribus delictis (21.05.2010), AAS 102(2010), s. 419-434.

9 KKK, nr 2464. 
skiej, która w konkretnych sytuacjach wymaga rozstrzygnięcia, czy należy ujawnić prawdę temu, kto jej żąda, czy nie"10. Zatem wolność, która przysługuje każdemu człowiekowi, nie upoważnia do mówienia i czynienia wszystkiego. Dla dobra i bezpieczeństwa drugiej osoby nie wolno ujawniać wszystkich posiadanych informacji, zachowując rozsądek i roztropnośćc ${ }^{11}$. Można więc powiedzieć, że prawdomówność jest nie tylko ściśle związana z dyskrecją, ale jest jej również podporządkowana. Dyskrecja to innymi słowy nieujawnianie wiedzy powierzonej w sekrecie, dla dobra bliźniego, a także ze względu na szacunek do prywatności ${ }^{12}$. Tajemnicą zaś są dane lub informacje, których ujawnienie osobom nieuprawnionym jest zakazane ze względu na moralność lub normy prawne ${ }^{13}$. Należy zatem powiedzieć, że tajemnica spowiedzi polega na najściślejszym obowiązku milczenia o grzechach usłyszanych podczas spowiedzi i należy ją rozumieć jako bezwzględny obowiązek spowiednika nieujawniania tego wszystkiego, o czym dowiedział się ze spowiedzi sakramentalnej, a co gdyby zostało podane do wiadomości, ujawniłoby osobę penitenta oraz spowodowałoby niechęć lub odrazę do sakramentu pokuty ${ }^{14}$.

Obowiązek zachowania tajemnicy spowiedzi nie zawsze był w Kościele oczywisty i kształtował się przez wieki. W Kościele pierwotnym bywało, iż grzechy wyznawano publicznie, dlatego też nie tworzono prawa regulującego zagadnienia zdrady tajemnicy spowiedzi. Dopiero Sobór Laterański IV (1215) ustanowił zakaz, który informował spowiednika, iż nie wolno mu słowem, znakiem albo jakimś innym sposobem zdradzić penitenta, bez względu na okoliczności. Sobór nałożył jednocześnie sankcje karne grożące za naruszenie tajemnicy spowiedzi ${ }^{15}$. Regulacje te potwier-

10 Tamże, nr 2488.

11 Por. KKK, nr 1740.

12 Por. kan. 220 KPK; por. J. Gręźlikowski, Idea i gwarancje ochrony danych osobowych oraz prawa do prywatności i intymności w Kościele, „Ateneum Kapłańskie” 140 (2003), z. 2(564), s. 272-288.

${ }_{13}$ Por. D. Adamczyk, Dyskrecja i tajemnica wyrazem szacunku dla prawdy, „Communio” 2 (2005), s. 131.

${ }^{14}$ Por. T. Pawluk, Prawo kanoniczne według Kodeksu Jana Pawła II, t. 4: Doczesne dobra Kościoła, sankcje w Kościele, procesy, Olsztyn 1990, s. 143.

15 „Kto odważył się ujawnić odkryty sobie w sądzie spowiedzi grzech, ten według naszego postanowienia nie tylko powinien być złożony z kapłańskiego urzędu, lecz także wtrącony do surowego klasztoru, aby ustawicznie odbyć pokutę". Sobór Laterański IV, 
dził Sobór Trydencki (1545-1563), wskazując na jego części składowe oraz sędziowski charakter rozgrzeszenia ${ }^{16}$. Późniejsze ustawodawstwo kościelne nie wprowadzało już zasadniczych zmian do uchwalonego postanowienia, precyzując jednakże dekret soborowy przez jeszcze bardziej szczegółowe wskazania co do tajemnicy spowiedzi ${ }^{17}$. Dopiero w 1915 r., po występowaniu pewnych nadużyć co do korzystania $\mathrm{z}$ informacji zdobytych podczas spowiedzi w rozmowach prywatnych i wykorzystywaniu ich podczas kazań przez niektórych spowiedników, Kongregacja Świętego Oficjum w dniu 9 czerwca tegoż roku wydała instrukcję, w której wskazała, iż nie należy posługiwać się materią spowiedzi w żadnych okolicznościach ${ }^{18}$. Dwa lata później został promulgowany przez papieża Benedykta XV Kodeks Prawa Kanonicznego, który w kan. $889 \$ 1$ wskazał, że tajemnica spowiedzi jest nienaruszalna, w związku z czym obowiązkiem szafarza sakramentu pokuty jest chronienie wiadomości powziętych podczas spowiedzi, tak by słowem, znakiem lub jakimkolwiek innym sposobem nie zdradzali penitenta ${ }^{19}$. W kanonie następnym Kodeks stanowił, iż szafarzowi sakramentu pokuty i pojednania nie wolno ujawniać informacji uciążliwych dla penitenta, nawet jeśli nie istnieje niebezpieczeństwo zdrady tajemnicy spowiedzi ${ }^{20}$. Nienaruszalność tajemnicy spowiedzi ówczesny prawodawca kodeksowy z 1917 r. opierał nie tylko na prawie kościelnym, ale przede wszystkim na prawie Bożym, wskazując tym samym, że określone unormowanie nie może ulec istotnej zmianie w przyszłości ${ }^{21}$.

Stąd też powyższe przepisy zostały niejako powtórzone w Kodeksie Prawa Kanonicznego Jana Pawła II z 1983 r. i niezmieniona pozostała dyscyplina o tajemnicy spowiedzi i obowiązku zachowania sekretu. Zagadnienie odnoszące się do tajemnicy spowiedzi sakramentalnej prawo-

Obowiązki spowiednika, [w:] Breviarium fidei. Wybór doktrynalnych wypowiedzi Kościoła, Poznań 2007, s. 114; por. T. Rakoczy, Ochrona tajemnicy spowiedzi. Zakaz wyjawiania okoliczności uciążliwych dla penitenta, „Annales Canonici” 7 (2011), s. 133.

16 Coc. Trid., sess. XIV, c. 1-9 de poenitentiae.

17 M. Pastuszko, Obowiązki szafarza sakramentu pokuty i pojednania, „Prawo Kanoniczne" 39 (1996), nr 1-2, s. 24-25.

${ }_{18}$ M. Pastuszko, Sakrament pokuty i pojednania, Kielce 1999, s. 406.

19 Kan. 889 \& 1 KPK z 1917 r.

${ }^{20}$ Kan. 890 KPK z 1917 r.

${ }^{21}$ M. Pastuszko, Obowiązki szafarza, s. 32. 
dawca kościelny uregulował w kan. 983 i 984. Polega ona na zachowaniu w tajemnicy wszelkich faktów, o których szafarz sakramentu pokuty i pojednania dowiaduje się podczas spowiedzi danej osoby. Zobowiązany jest zachować w tajemnicy wyznane grzechy, okoliczności ich popełnienia, ewentualnych wspólników i wszystkie inne informacje zdobyte $\mathrm{w}$ akcie spowiedzi ${ }^{22}$. Tajemnica spowiedzi jest nienaruszalna. Oznacza to, że spowiednik bez względu na przyczynę nie może zdradzić faktów usłyszanych podczas spowiedzi świętej, czy to słowami, czy w jakikolwiek inny sposób $^{23}$. Kościół nie zezwala na żadne formy naruszenia tajemnicy spowiedzi sakramentalnej i nie usprawiedliwia żadnej okoliczności, która mogłaby mieć wpływ na ujawnienie informacji powziętych podczas spowiedzi ${ }^{24}$. Od zobowiązania do zachowania tajemnicy spowiedzi Kościół nie może też dyspensować, ponieważ zakaz ujawniania wiadomości powziętych podczas sakramentu pokuty nie pochodzi tylko z prawa czysto kościelnego, czyli ludzkiego, ale przede wszystkim z prawa Bożego ${ }^{25}$. Zachowanie tajemnicy spowiedzi obowiązuje spowiednika do końca jego życia i nawet sytuacja zagrażająca bezpieczeństwu szafarza nie zwalnia go z obowiązku milczenia. Usprawiedliwieniem dla niedochowania tajemnicy nie jest również śmierć penitenta ${ }^{26}$. Powyższa dyscyplina odnosząca się do zachowania tajemnicy spowiedzi wynika $\mathrm{z}$ bardzo wrażliwego i delikatnego charakteru sakramentu pokuty, wielkości posługi spowiednika, jak też ma na celu ochronę świętości i godności tego sakramentu.

Jednocześnie prawodawca kościelny w kan. 984 bezwzględnie zabrania spowiednikowi korzystania $\mathrm{z}$ wiadomości uzyskanych podczas spowiedzi, powodujących uciążliwość dla penitenta, nawet przy wyklu-

22 Por. D. Borek, Przestępstwa przeciwko sakramentom $w$ normach de delictis reservatis $z 2010$ roku, „Prawo Kanoniczne” 55 (2012), nr 4, s. 146.

${ }^{23}$ Kan. 983 KPK. Prawodawca kodeksowy w tym samym kanonie nakazuje również zachowanie sekretu spowiedzi tłumaczowi, jeśli występuje podczas spowiedzi sakramentalnej, jak też wszystkim innym, którzy w jakikolwiek sposób zdobyli ze spowiedzi wiadomości o grzechach. W odniesieniu do tłumacza użyty jest termin secretum, podczas gdy do spowiednika termin sacramentale sigillum.

${ }^{24}$ W. Wenz, Całkowita nienaruszalność tajemnicy sakramentalnej w posługiwaniu kościelnym wszystkich kapłanów, [w:] Jan Paweł II - obrońca godności człowieka. Materiały z III tygodnia kultury chrześcijańskiej w diecezji świdnickiej, Świdnica 2008, s. 98-99.

25 J. Syryjczyk, Kościelne prawo karne. Część szczególna, Warszawa 2003, s. 129.

${ }^{26}$ W. Wenz, Całkowita nienaruszalność tajemnicy sakramentalnej, s. 102. 
czeniu wszelkiego niebezpieczeństwa wyjawienia ${ }^{27}$. Regulacja ta została stworzona w celu podkreślenia, że zakazu używania informacji zdobytych podczas spowiedzi nie należy rozumieć tylko jako niezezwolenia na naruszenie tajemnicy spowiedzi, ale $\mathrm{w}$ znaczeniu szerszym, a mianowicie jako bezwzględny zakaz korzystania $\mathrm{z}$ wiadomości nabytych podczas spowiedzi sakramentalnej ${ }^{28}$. Chodzi tutaj o ochronę niezbywalnych praw penitenta. W tym celu paragraf drugi tegoż kanonu zakazuje przełożonym kościelnym korzystania $\mathrm{w}$ zewnętrznym zarządzaniu instytucjami $\mathrm{z}$ informacji o grzechach wyznawanych podczas spowiedzi przez członków danej instytucji ${ }^{29}$. Należy pamiętać, iż mimo faktu, że obowiązek zachowania tajemnicy spowiedzi odnosi się do szafarza sakramentu pokuty i pojednania, a więc penitent nie jest podmiotem tej normy, to jednak powinien penitent strzec tego, co usłyszy od spowiednika oraz co sam wyznał w oparciu na zasadach sekretu naturalnego ${ }^{30}$.

Przedstawione normy kodeksowe (kan. 983 i 984) zdecydowanie i jednoznacznie chronią tajemnicę spowiedzi. Zdrada tajemnicy spowiedzi jest zawsze niedopuszczalna i naganna. Nigdy nie wolno wyjawiać informacji zdobytych podczas spowiedzi, nawet jeśli takie wyjawienie nie wiązałoby się ze zdradą tajemnicy spowiedzi. Także wtedy, kiedy nie ma niebezpieczeństwa ujawnienia tajemnicy spowiedzi i wyrządzenia szkody osobie penitenta, zakazuje się wykorzystywania wiadomości uciążliwych dla penitenta.

Tajemnica spowiedzi chroniona jest nie tylko normami kanonicznymi, ale prawodawca kościelny chroni ją poprzez zakaz przesłuchiwania duchownych na okoliczności poznane podczas spowiedzi. Według kan. $1550 \$ 2$ KPK za niezdolnych do stawienia się w sądzie w charakterze świadków uważa się kapłanów w odniesieniu do wszystkiego, co poznali z sakramentalnej spowiedzi, chociażby penitent prosił o ujawnienie tego. Zaś „tego, co przez kogokolwiek i w jakikolwiek sposób zostało usłyszane $\mathrm{z}$ okazji spowiedzi, nie można w sądzie przyjąć nawet jako śladu prawdy" ${ }^{31}$. Celem powyższych norm kanonicznych jest zagwarantowanie

\footnotetext{
27 Kan. 984 KPK.

28 D. Adamczyk, Dyskrecja i tajemnica, s. 133-134.

${ }^{29}$ Kan. $984 \$ 2$ KPK; por. M. Pastuszko, Sakrament pokuty, s. 409-410.

30 A. Drożdż, Sakrament pojednania z Bogiem i Kościołem, Tarnów 1994, s. 115.

${ }^{31}$ Kan. $1550 \$ 2$ KPK.
} 
penitentowi zupełnej i bezwarunkowej dyskrecji, by czuł się swobodnie, bezpiecznie oraz miał zaufanie do szafarza sakramentu pokuty i pojednania. Nadto można powiedzieć, że zachowanie tajemnicy spowiedzi służy ochronie godności penitenta, jak i świętości sakramentu.

Podobne regulacje zawiera prawo polskie, uwzględniając normy prawne stosowane w prawie kanonicznym. Prawo karne procesowe wyłącza możliwość przesłuchania jako świadka duchownego co do faktów, o których dowiedział się $w$ trakcie spowiedzi ${ }^{32}$. Podobną regulację znajdujemy w kodeksie postępowania administracyjnego ${ }^{33}$, natomiast zgodnie z kodeksem postępowania cywilnego kapłan może odmówić złożenia zeznań co do faktów powierzonych mu na spowiedzi ${ }^{34}$.

Zachowanie tajemnicy spowiedzi należy do zasadniczych i głównych obowiązków spowiednika. Kiedy szafarz sakramentu pokuty złamie zakaz wyjawienia okoliczności uciążliwych dla penitenta lub dopuści się zdrady tajemnicy spowiedzi, naruszy tym samym prawo Boże naturalne i prawo kościelne ${ }^{35}$. Przez zdradę tajemnicy spowiedzi należy rozumieć sytuację, gdy szafarz sakramentu pokuty i pojednania, mówiąc wprost o konkretnej osobie (wymienia osobę z imienia i nazwiska lub wprawdzie nie wymienia jej z nazwiska, ale można $\mathrm{z}$ jego wypowiedzi wywnioskować, o kogo chodzi), wspomina o fakcie, który zna ze spowiedzi. Może to dotyczyć grzechów lub innych okoliczności życia penitenta ujawnionych podczas spowiedzi, a także faktu rozgrzeszenia lub jego braku. Aby można było mówić o zdradzie tajemnicy spowiedzi, musi się odbyć ważna jurydycznie spowiedź, ponieważ tylko taka jest spowiedzią sakramentalną. Szafarz sakramentu pokuty i pojednania jest zobowiązany do zachowania tajemnicy od momentu rzeczywistego wyznania grzechów penitenta. Nie ma znaczenia, czy zostało udzielone rozgrzeszenie, czy też nie, ani czy

${ }^{32}$ Ustawa z dnia 6.06.1997 r. - Kodeks postępowania karnego (Dz.U. z 1997 r., $\mathrm{Nr} 89$, poz. 555), art. 178.

33 Ustawa z dnia 14.06.1960 r. - Kodeks postępowania administracyjnego (Dz.U. z 1960 r., Nr 30, poz. 168), art. 82.

${ }^{34}$ Por. Ustawa z dnia 17.11.1964 r. - Kodeks postępowania cywilnego (Dz.U. z 1964 r., Nr 43, poz. 296), art. 261.

${ }_{35}$ M. Wielec, Zakaz dowodowy tajemnicy spowiedzi w postępowaniu karnym, Warszawa 2012, s. 85. 
spowiedź została dokończona, czy przerwana ${ }^{36}$. Obowiązku zachowania tajemnicy spowiedzi spowiednik nie zaciąga, jeśli spowiedź odbywała się z motywów pozapokutnych, np. w celu otrzymania porady albo wyszydzenia spowiednika, bądź dla zabawy ${ }^{37}$.

\section{FORMY NARUSZENIA TAJEMNICY SPOWIEDZI}

W prawodawstwie kościelnym naruszenie tajemnicy spowiedzi może przyjąć dwie zasadnicze formy, w zależności od ich intensywności. Można złamać tajemnicę spowiedzi bezpośrednio, czyli wprost, lub pośrednio, czyli ubocznie. Podział ten wprowadził w 1227 r. synod w Trewirze $^{38}$ i od tego czasu obowiązuje on w Kościele do dnia dzisiejszego.

\section{A. BEZPOŚREDNIA ZDRADA TAJEMNICY SPOWIEDZI}

Bezpośrednie niedochowanie tajemnicy sakramentu pokuty i pojednania (directa violatio) zachodzi, gdy szafarz sakramentu wyjawi wprost osobie trzeciej przedmiot tajemnicy spowiedzi oraz osobę penitenta ${ }^{39}$. Przez przedmiot spowiedzi rozumie się wyznane przez penitenta grzechy śmiertelne, jak i powszednie, tajne czy publiczne, jak też fizyczne czy psychiczne defekty po stronie penitenta, a także grzechy popełnione $\mathrm{w}$ akcie spowiedzi ${ }^{40}$. Szafarzowi sakramentu pokuty i pojednania zabrania się zatem ujawnienia grzechów penitenta. O grzechach ciężkich spowiednik nie ma prawa wspominać nawet w sposób ogólny, natomiast co do

36 Tamże, s. 87; por. W. Wenz, Całkowita nienaruszalność tajemnicy sakramentalnej, s. 104.

37 T. Pawluk, Prawo kanoniczne według Kodeksu Jana Pawła II, t. 4, 143.

38 Stwierdzał on, że „nie wolno żadnemu kapłanowi w sposób bezpośredni lub pośredni złamać - wyjawić tajemnicy spowiedzi. Nie wolno tego uczynić czy to gestem, czy to słowem, czy też jakimś znakiem, w szczegółach, bądź tylko ogólnie”. K. Kociński, Naruszenie tajemnicy spowiedzi $w$ prawie karnym kanonicznym i świeckim. Studium historyczno-prawne, Lublin 1971, s. 61.

39 W. Wenz, Całkowita nienaruszalność tajemnicy sakramentalnej, s. 104.

${ }^{40}$ M. Pastuszko, Obowiązki szafarza, s. 36. 
grzechów powszednich - nie wolno ujawniać ich rodzaju ${ }^{41}$. Rozmowa spowiednika z penitentem na temat tego, co stanowi przedmiot tajemnicy sakramentalnej, nie stanowi jej naruszenia, choćby rozmowa ta była bez zgody penitenta ${ }^{42}$

Drugim koniecznym elementem do zaistnienia bezpośredniej zdrady tajemnicy spowiedzi jest wyjawienie osoby penitenta przez szafarza sakramentu pokuty. Może tego dokonać wprost, wyraźnie mówiąc o konkretnej osobie, podając jej imię i nazwisko, lub przez kontekst okolicznościowy, to znaczy nie mówiąc konkretnie ,o kogo chodzi, ale biorąc pod uwagę kontekst wypowiedzi osoba trzecia domyśli się, o kim jest mowa ${ }^{43}$. Do zdrady tajemnicy spowiedzi dojdzie nawet wtedy, gdy osoba trzecia nie będzie wiedziała, że szafarz ujawnia jej fakty usłyszane podczas spowiedzi ${ }^{44}$.

Przy bezpośredniej zdradzie tajemnicy spowiedzi istotne jest zachowanie spowiednika. Najpierw musi on dokonać zdrady z winy umyślnej, tzn. ujawniając fakty usłyszane podczas sprawowania sakramentu pokuty musi mieć wolę złamania norm prawa Bożego i kościelnego ${ }^{45}$. A zatem, aby spowiednikowi przypisać zdradę tajemnicy spowiedzi, musi on mieć świadomość, że ujawnia informacje zdobyte podczas spowiedzi, inaczej mówiąc winien on mieć świadomość złamania normy prawnej ${ }^{46}$. W prawie kanonicznym bowiem obowiązuje zasada, że „nie można nikogo karać, jeśli popełnione przez niego zewnętrzne naruszenie ustawy lub nakazu nie jest ciężko poczytalne na skutek winy umyślnej lub nieumyślnej”"47.

Podmiotem dokonującym bezpośredniego naruszenia tajemnicy spowiedzi może być tylko spowiednik, szafarz sakramentu pokuty i pojed-

${ }^{41}$ Por. Jan Paweł II, Tajemnica spowiedzi świętej. Przemówienie do członków Penitencjarii Apostolskiej dnia 12 marca 1994 r., „L'Osservatore Romano”, wyd. polskie, 5 (1994), s. 21.

${ }^{42}$ Por. T. Pawluk, Prawo kanoniczne według Kodeksu Jana Pawła II, t. 4, 144.

${ }^{43}$ W. Wenz, Całkowita nienaruszalność tajemnicy sakramentalnej, s. 104-105.

${ }_{44}$ D. Borek, Przestępstwa przeciwko sakramentom, s. 148.

${ }^{45}$ Kan. $1321 \S 2$ KPK; por. M. Wielec, Zakaz dowodowy tajemnicy spowiedzi, s. 88 .

${ }^{46}$ D. Borek, Przestęstwa przeciwko sakramentom, s. 148.

${ }^{47}$ Kan. $1321 \S 1$ KPK. 
nania ${ }^{48}$. Prawodawca kościelny - co zostało już wspomniane - w kanonach traktujących o tajemnicy spowiedzi rozróżnia dwa terminy: sacramentale sigillum (tajemnica sakramentalna) i secretum (sekret) ${ }^{49}$. Pierwszy odnosi się do szafarza sakramentu pokuty, drugi do tłumacza, jeśli występuje podczas spowiedzi sakramentalnej i do tych wszystkich, którzy w jakikolwiek sposób zdobyli ze spowiedzi wiadomości o grzechach. Przedmiot tajemnicy i sekretu jest ten sam, a ich naruszenie jest grzechem, a ponadto przestępstwem, za które przewidziana jest sprawiedliwa kara ${ }^{50}$. Różnicą dla obu pojęć jest podmiot, który przestępstwa może dokonać. Naruszyć tajemnicę spowiedzi, a więc dokonać przestępstwa - w myśl kan. 1388 $\$ 1 \mathrm{KPK}$ - może tylko szafarz sakramentu pokuty i pojednania. Podlega on karze ekskomuniki wiążącej mocą samego prawa, zastrzeżonej Stolicy Apostolskiej ${ }^{51}$. Tłumacz zaś lub inna osoba, która słyszała spowiedź, są zobowiązane do sekretu spowiedzi. Jeżeli sekret ten naruszają, „powinni być ukarani sprawiedliwą karą, nie wyłączając ekskomuniki”"52. Zatem, w myśl norm kanonicznych, szafarz sakramentu pokuty i pojednania zobligowany jest zachować tajemnicę sakramentalną, natomiast tłumacz lub inna osoba, która umyślnie lub przez przypadek usłyszała grzechy wyjawione w akcie spowiedzi, zobowiązana jest do dochowania sekretu spowiedzi.

\section{B. POŚREDNIA ZDRADA TAJEMNICY SPOWIEDZI}

Naruszenie tajemnicy spowiedzi w sposób pośredni (indirecta violatio) następuje wtedy, gdy osoba zobowiązana do zachowania tajem-

${ }^{48}$ Por. kan. 1388 \$ $1 \mathrm{KPK}$.

49 Por. kan. 983 KPK. To rozróżnienie na sacramentale sigillum i secretum znajduje się w wersji łacińskiej Kodeksu, tłumaczenie zaś polskie tego rozróżnienia nie zawiera, gdyż secretum przetłumaczono jako tajemnicę, a nie sekret. Analogiczna sytuacja dotyczy kan. 1388, który w paragrafie pierwszym traktuje o zdradzie tajemnicy spowiedzi, natomiast w paragrafie drugim o naruszeniu sekretu spowiedzi.

${ }^{50}$ M. Wielec, Zakaz dowodowy tajemnicy spowiedzi, s. 88; por. J. Syryjczyk, Kościelne prawo karne, s. 131.

${ }^{51}$ Kan. 1388 \$ 1 KPK; por. M. Pastuszko, Obowiązki szafarza, s. 37.

${ }^{52}$ Kan. 1388 \$ 2 KPK; por. M. Wielec, Zakaz dowodowy tajemnicy spowiedzi, s. $83-84$. 
nicy sakramentalnej wyjawi przedmiot spowiedzi, czyli wyznane grzechy, lecz bez ujawniania osoby penitenta, lub odwrotnie, czyli nie zdradzając grzechów, poda dane spowiadającego się, stwarzając możliwość zidentyfikowania. Im większa możliwość takiego wnioskowania, naruszenie pośrednie upodabnia się do naruszenia bezpośredniego ${ }^{53}$. Chodzi zatem o sytuacje, kiedy spowiednik swoim odezwaniem się lub postępowaniem stwarza niebezpieczeństwo wyjawienia osoby penitenta i tego, co podlega tajemnicy sakramentalnej. Najczęstszym przykładem niedochowania tajemnicy spowiedzi w sposób pośredni jest niezachowanie należytej ostrożności przez spowiednika przez korzystanie $\mathrm{z}$ wiedzy zdobytej podczas spowiedzi dla zilustrowania konkretnej sytuacji życiowej podczas głoszenia kazań czy homilii. Należy jednak zaznaczyć, iż aby zaistniała pośrednia zdrada tajemnicy spowiedzi, musi być ona popełniona $\mathrm{z}$ winy umyślnej, tzn. spowiednik winien mieć świadomość, że korzysta z informacji zdobytych podczas spowiedzi, innymi słowy musi tego dokonać $\mathrm{z}$ intencją naruszenia prawa ${ }^{54}$.

Zaleca się jednak, aby szafarze sakramentu pokuty i pojednania nie prowadzili żadnych dyskusji czy rozmów dotyczących doświadczeń ze sprawowania tego sakramentu ${ }^{55}$. Jeżeli natomiast zdarzy się sytuacja, iż spowiednik będzie potrzebował porady, gdyż ich przygotowanie przewyższa ocenę i rozstrzygnięcie problemów związanych ze sprawowaniem sakramentu pokuty i pojednania, to „po rozważeniu pilności sprawy i stanu psychicznego penitenta oraz innych okoliczności, roztropność duszpasterska połączona z pokorą winna kazać spowiednikowi odesłać penitenta do innego kapłana lub wyznaczyć inne spotkanie, do którego spowiednik będzie się mógł lepiej przygotować. Można też, bez narażania na szwank tajemnicy spowiedzi, zwrócić się o pomoc do kapłanów lepiej przygotowanych i mających większe doświadczenie" ${ }^{36}$. Jest to zalecenie św.

${ }^{33}$ Codex Iuris Canonici. Kodeks prawa kanonicznego. Komentarz, red. P. Majer, Kraków 2011, s. 1083.

54 Por. D. Borek, Przestępstwa przeciwko sakramentom, s. 148-149.

${ }_{55}$ M. Pastuszko, Sakrament pokuty, s. 406; por. T. Rakoczy, Ochrona tajemnicy spowiedzi, s. 139-140.

${ }^{56}$ Jan Paweł II, Posługa kapłańska w sakramencie pojednania. Przemówienie do członków Penitencjarii Apostolskiej dnia 27 marca 1993 r., „L’Osservatore Romano”, wyd. polskie, 5-6 (1993), s. 44. 
Jana Pawła II, a wynika ono z faktu, że prawodawca kościelny w obecnym Kodeksie kwestii tej nie reguluje. Ponieważ zakaz korzystania z wiedzy zdobytej podczas spowiedzi jest bezwzględny ${ }^{57}$, każde wykorzystanie czy ujawnienie faktów znanych ze spowiedzi jest naruszeniem tajemnicy sakramentalnej. W związku z powyższym, skoro prawodawca kościelny w sposób precyzyjny przedstawił strukturę spowiedzi, w sytuacji kiedy spowiednik uzna się za niekompetentnego, musi skorzystać z innego rozwiązania, zgodnego z prawem kanonicznym ${ }^{58}$.

Zgodnie z obowiązującymi normami kanonicznymi podmiotem zdolnym w sposób pośredni zdradzić tajemnicę spowiedzi, analogicznie do bezpośredniego naruszenia tajemnicy sakramentu pokuty i pojednania, jest spowiednik, czyli biskup lub prezbiter, który ujawni informacje powzięte przy okazji sprawowania sakramentu pokuty i pojednania ${ }^{59}$.

\section{SANKCJE KARNE ZA ZDRADĘ TAJEMNICY SPOWIEDZI}

Zdrada tajemnicy spowiedzi sakramentalnej dokonana przez spowiednika została w Kościele uznana za jedno z najpoważniejszych i najcięższych przestępstw. Wynika to $\mathrm{z}$ faktu wartości i znaczenia sakramentu pokuty i pojednania, jak też troski o jego ważne i godne sprawowanie ${ }^{60}$. Przestępstwo naruszenia tajemnicy sakramentalnej godzi w świętość sakramentu pokuty, czyni go uciążliwym, naraża penitenta na zniesławienie oraz zrywa naturalną umowę między penitentem a spowiednikiem. Z powyższych racji prawodawca kościelny ma obowiązek zadbać o ochronę tego sakramentu, do sprawowania którego niezbędne jest zaufanie wiernych, poczucie bezpieczeństwa i pewność, że ich grzechy wyjawione podczas spowiedzi będą chronione tajemnicą. Dlatego szafarz sakramentu

${ }^{57}$ Kan. $984 \$ 1$ KPK; por. M. Wielec, Zakaz dowodowy tajemnicy spowiedzi, s. $85-86$.

58 Por. T. Rakoczy, Ochrona tajemnicy spowiedzi, s. 141.

${ }^{59}$ Por. kan. $983 \$ 1$ KPK.

${ }^{60}$ Przestępstwo w kanonicznym prawie karnym jest zewnętrznym naruszeniem ustawy lub nakazu karnego, poważnie poczytalnym, na skutek winy umyślnej lub nieumyślnej. Por. kan. 1321 KPK; J. Syryjczyk, Sankcje w Kościele. Część ogólna. Komentarz, Warszawa 2008, s. 120-121. 
pokuty i pojednania, który dopuści się złamania zakazu ustanowionego w kan. $893 \$ 1$ i $984 \$ 1 \mathrm{KPK}$, podlega odpowiednim sankcjom karnym i to zarezerwowanym Stolicy Apostolskiej ${ }^{61}$. Karalność za przestępstwo zdrady tajemnicy spowiedzi (bezpośrednie i pośrednie) - w myśl norm kanonicznego prawa karnego - przedawnia się po upływie dziesięciu lat od dnia ich popełnienia ${ }^{62}$.

Sankcje karne za przestępstwo bezpośredniego i pośredniego naruszenia tajemnicy spowiedzi zostały uregulowane w kan. $1388 \$ 1 \mathrm{KPK}$, gdzie czytamy: „spowiednik, który narusza bezpośrednio tajemnicę sakramentalną, podlega ekskomunice wiążącej mocą samego prawa, zastrzeżonej dla Stolicy Apostolskiej. Gdy zaś narusza ją tylko pośrednio, powinien być ukarany stosownie do ciężkości przestępstwa"63. W przypadku bezpośredniego naruszenia tajemnicy spowiedzi podmiotem kompetentnym do zwolnienia $\mathrm{z}$ kary zaciągniętej za popełnione przestępstwo jest Stolica Apostolska, do której należy się zwrócić, aby zdjęła ze spowiednika karę ekskomuniki. Natomiast pośrednia zdrada została obwarowana lżejszą sankcją karną, mianowicie karą ferendae sententiae, która może zostać wymierzona jedynie po przeprowadzeniu przez kompetentny podmiot odpowiedniej procedury ${ }^{64}$. Ustawodawca kościelny nie określił $\mathrm{w}$ sposób wyraźny rodzaju sankcji karnej, lecz zostawił osobie wymierzającej karę swobodę w ocenie. Rodzaj kary i jej wielkość zależeć będzie w tym przypadku od przesłanek przedmiotowych i podmiotowych popełnionego przestępstwa oraz wyrządzonej szkody. W myśl norm kanonicznych będzie to cenzura: ekskomunika, interdykt, suspensa lub kara ekspijacyjna ${ }^{65}$.

Powyższe regulacje prawne, jakie zostały określone w Kodeksie Prawa Kanonicznego z 1983 r., zostały w pewnych aspektach zmienione przez papieża Jana Pawła II, który 30 kwietnia 2001 r. ustanowił i promulgował listem apostolskim motu proprio Sacramentorum sanctitatis tutela normy De gravioribus delictis, które określały najcięższe przestępstwa

${ }^{61}$ Por. kan. $1388 \$ 1 \mathrm{KPK}$.

${ }^{62}$ Kan. $1362 \$ 1$ KPK; por. J. Syryjczyk, Sankcje w Kościele, s. 321-323; D. Borek, Concursus in delicto. Formy zjawiskowe przestępstwa w kanonicznym prawie karnym (studium prawno-historyczne), Warszawa 2014, s. 71-75.

${ }^{63}$ Kan. $1388 § 1$ KPK.

${ }^{64}$ D. Borek, Przestępstwa przeciwko sakramentom, s. 90.

${ }^{65}$ Por. J. Syryjczyk, Sankcje w Kościele, s. 131 oraz 313-323. 
przeciwko sakramentom i obyczajom, w tym w stosunku do sakramentu pokuty i pojednania, wskazywały przepisy proceduralne co do stosowania sankcji kanonicznych i ich nakładania oraz regulowały kwestię odpowiedzialności za ich popełnienie, rezerwując ich rozstrzyganie Kongregacji Nauki Wiary ${ }^{66}$. Normy te następnie uszczegółowił i zmienił w pewnych elementach papież Benedykt XVI, w dniu 21 maja 2010 r. wydając normy De delictis reservatis ${ }^{67}$.

Zgodnie z normami De gravioribus delictis najcięższymi przestępstwami przeciwko sakramentowi pokuty i pojednania są: rozgrzeszenie wspólnika w grzechu przeciwko szóstemu przykazaniu Dekalogu, sollicitatio ad turpia, jeżeli ma na celu grzech $\mathrm{z}$ samym spowiednikiem ${ }^{68}$, oraz bezpośrednie naruszenie tajemnicy spowiedzi ${ }^{69}$. Możliwość zwolnienia z kary za powyższe przestępstwa została zarezerwowana Kongregacji Nauki Wiary. Warto zauważyć, że w normach tych nie została wyszczególniona pośrednia zdrada tajemnicy spowiedzi ${ }^{70}$. Zwolnienie to należy rozumieć jako zdjęcie z osoby ukaranej obowiązku, który za pomocą owej kary został nałożony. W powyższym przypadku tylko Kongregacja Nauki Wiary może zwolnić z kary zaciągniętej przez popełnienie przestępstw wymienionych wyżej. Dopóki tego Kongregacja nie zrobi, na przestępcy będzie ciążyła sankcja karna ${ }^{71}$.

${ }^{66}$ Joannes Paulus II, Litterae Apostolacie motu proprio datae quibus Normae de gravioribus delictis Congregationi pro Doctrina Fidei reservatis promulgantur, Sacramentorum sanctitatis tutela, s. 737-739.

${ }^{67}$ Congregatio pro Doctrina Fidei, Normae de delictis Congregationi pro Doctrina Fidei reservatis seu Normae de delictis contra Fidem necnon de gravioribus delictis, s. 419-434; por. M. Stokłosa, Modyfikacje wprowadzone do tekstu Norme de gravioribus delictis, „Prawo i Kościół” 3 (2011), s. 147-172.

${ }^{68}$ Mówi o nim kan. 1387 KPK. Przestępstwo to polega na nakłanianiu do grzechu przeciwko szóstemu przykazaniu Dekalogu albo w akcie spowiedzi, albo przy okazji spowiedzi lub też pod jej pretekstem. Por. D. Borek, Sextum Dekalogi praeceptum w kanonicznym prawie karnym aktualnie obowiązującym, Tarnów 2015, s. 91-92.

${ }^{69}$ Congregatio pro Doctrina Fidei, Normae de delictis Congregationi pro Doctrina Fidei reservatis seu Normae de delictis contra Fidem necnon de gravioribus delictis, s. 429.

${ }^{70}$ Por. D. Borek, Sextum Dekalogi praeceptum w kanonicznym prawie karnym aktualnie obowiązującym, s. 88-97.

${ }^{71}$ Kwestie te w sposób ogólny reguluje kan. $1354 \$ 3$ KPK, który rozróżnia kary zastrzeżone Stolicy Apostolskiej i kary niezastrzeżone. Owo zastrzeżenie polega na odebraniu możliwości zwolnienia z kary niższym przełożonym, udzielając go przełożonym 
Do powyższych uszczegółowionych przepisów, kierując się potrzebą udoskonalenia prawa, papież Benedykt XVI wprowadził pewne modyfikacje w 2010 r., zmieniając niektóre teksty i dyspozycje norm promulgowanych przez Jana Pawła II z 2001 r. Noszą one nazwę - jak już wspomniano - normy De delictis reservatis ${ }^{72}$. Tematyce przestępstw przeciwko sakramentowi pokuty i pojednania został poświęcony art. 3 wspomnianych norm. W paragrafie pierwszym tego artykułu czytamy, że „najcięższe przestępstwa przeciwko sakramentowi pokuty zastrzeżone do kompetencji Kongregacji Nauki Wiary są następujące: 1. absolucja udzielona wspólnikowi $\mathrm{w}$ grzechu przeciw szóstemu przykazaniu Dekalogu, o którym mówi kan. 1378 \$ 1 KPK oraz kan. 1457 Kodeksu Kanonów Kościołów Wschodnich; 2. usiłowanie udzielenia absolucji lub zabronione słuchanie spowiedzi, o którym mówi kan. $1378 \$ 2$ p. 2 KPK; 3. symulowanie absolucji sakramentalnej, o której mówi kan. 1379 KPK oraz kan. 1443 Kodeksu Kanonów Kościołów Wschodnich; 4. nakłanianie do grzechu przeciw szóstemu przykazaniu Dekalogu w akcie, z okazji lub pod pretekstem spowiedzi, o którym mówi kan. 1387 KPK oraz kan. 1458 Kodeksu Kanonów Kościołów Wschodnich, jeżeli nakłanianie dotyczy popełnienia grzechu ze spowiednikiem; 5 . bezpośrednie lub pośrednie zerwanie tajemnicy sakramentalnej, o której mówi kan. $1388 \$ 1$ KPK oraz kan. $1456 \S 1$ Kodeksu Kanonów Kościołów Wschodnich”73.

wyższego stopnia, w tym przypadku Kongregacji Nauki Wiary. Prawodawca kodeksowy wskazał bowiem, że Stolica Apostolska może zarezerwować sobie lub innemu podmiotowi możliwość zwolnienia z kary, co należy interpretować w sposób ścisły, czyli tylko wskazany przez nią podmiot jest kompetentny do uwolnienia przestępcy. Por. J. Syryjczyk, Sankcje w Kościele, s. 291 i 293-295.

72 Zostały one podzielone na dwie części. Pierwsza część nosi nazwę normy zasadnicze i składa się z siedmiu artykułów. Traktuje ona o kompetencjach Kongregacji Nauki Wiary, wylicza przestępstwa zaliczone do kategorii najcięższych przestępstw delicta reservata oraz wskazuje terminy przedawnienia czynów karalnych za ich popełnienie, w stosunku do których Kongregacja Nauki Wiary jest Najwyższym Trybunałem Apostolskim. Druga część została zatytułowana normy proceduralne i zawiera szczegółowe dyspozycje określające sposób i formę zachowania w przypadku zaistnienia przestępstwa zastrzeżonego Kongregacji Nauki Wiary. Por. D. Borek, Przestępstwa przeciwko sakramentom, s. 111-113; tenże, Sextum Dekalogi praeceptum w kanonicznym prawie karnym aktualnie obowiąujacym..., s. 103-104.

${ }^{73}$ Congregatio pro Doctrina Fidei, Normae de delictis Congregationi pro Doctrina Fidei reservatis seu Normae de delictis contra Fidem necnon de gravioribus delictis, s. 428. 
Już na pierwszy rzut oka widać, że w normach z 2010 r. w porównaniu z normami z 2001 r., nastąpił wzrost liczby przestępstw przeciwko sakramentowi pokuty i pojednania, co z jednaj strony może świadczyć o trosce prawodawcy kościelnego o prawidłowe i godziwe sprawowanie tego sakramentu oraz wykluczenie różnych nadużyć i nieprawidłowości, a z drugiej strony może też wskazywać na problem łamania prawa kościelnego ${ }^{74}$. Nadal oczywiście obowiązują uregulowania kodeksowe traktujące tajemnicę sakramentu spowiedzi jako bezwzględnie nienaruszalną ${ }^{75}$, a regulacje zawarte w normach De delictis reservatis z 2010 r. stanowią niejako uzupełnienie i uszczegółowienie norm kodeksowych. Normy te regulują przestępstwo niedochowania tajemnicy spowiedzi ogólnie, jako czyn zabroniony, lecz w podwójnym ujęciu - zdrady bezpośredniej i pośredniej. Ponadto wprowadzają zmiany obejmujące okoliczności popełnienia przestępstwa przeciwko sakramentowi pokuty i pojednania, które zawarte są w kan. $1378 \$ 2$ p. 2 KPK, a mianowicie usiłowanie udzielenia absolucji sakramentalnej bez możliwości jej ważnego udzielenia lub zabronione słuchanie sakramentalnej spowiedzi, jak też regulują kwestię symulowania absolucji sakramentalnej (art. $4 \$ 1$, nr 2 i 3). Regulacje te przedstawiają także okoliczności bezpośredniej i pośredniej zdrady tajemnicy sakramentalnej (art. $4 \$ 1$, nr 5) oraz kwestię nagrywania i rozpowszechniania treści spowiedzi świętej, zgodnie z dekretem Kongregacji Nauki Wiary z 23 września 1988 r. (art. $4 \$ 2)^{76}$.

$* * *$

Sakrament pokuty i pojednania jest znakiem pojednania Boga z ludźmi, a sprawowany we wspólnocie Kościoła stanowi „radosną celebrację miłości Boga, który daje siebie, niszcząc nasz grzech, gdy go

${ }^{74}$ Por. D. Borek, Przestęstwa przeciwko sakramentom, s. 135.

${ }^{75}$ Por. kan. $983 \$ 1 \mathrm{KPK}$; por. W. Wenz, Całkowita nienaruszalność tajemnicy sakramentalnej, s. 98-99.

${ }^{76}$ Kongregacja Nauki Wiary, Opracowanie dotyczace zmian wprowadzonych $w$ dokumencie „Normae de gravioribus delictis” zastrzeżonych dla Kongregacji Nauki Wiary, „Anamnesis” 63 (2010), s. 51-52. 
pokornie uznajemy"77. Niosąc doświadczenie przebaczenia i stanowiąc jeden z elementów tworzących drogę do zbawienia, zobowiązuje szafarza do pokornej i dyspozycyjnej służby wobec osób pragnących doświadczyć Bożego Miłosierdzia ${ }^{78}$. Jednocześnie zobowiązuje szafarza do roztropności, wrażliwości i delikatności, a przede wszystkim, pod surowymi karami, do zachowania absolutnej tajemnicy odnośnie do grzechów wyznawanych przez penitenta.

Tajemnica spowiedzi jest bezwzględnie nienaruszalna, a Kościół stoi na straży ochrony tajemnicy sakramentalnej i troski o ważne i godziwe sprawowanie sakramentu pokuty i pojednania. Nienaruszalność tajemnicy sakramentalnej wywodzi się nie tylko z prawa kościelnego, ale przede wszystkim ma podstawę w prawie Bożym. Ze względu na powagę, wartość i znaczenie tego sakramentu spowiednik został zobligowany do zachowania tajemnicy spowiedzi, która obowiązuje go do końca życia i nie ustaje nawet po śmierci penitenta. Żadna też władza na ziemi nie może zwolnić lub dyspensować spowiednika od obowiązku zachowania tajemnicy sakramentalnej.

Tajemnica spowiedzi jest chroniona na wielu obszarach. $Z$ jednej strony przez zabranianie pod groźbą kary korzystania $\mathrm{z}$ wiadomości zdobytych $\mathrm{w}$ akcie spowiedzi, następnie przez zakaz przesłuchiwania duchownych jako świadków na okoliczności poznane podczas spowiedzi. Z drugiej strony prawodawstwo świeckie z szacunku dla Kościoła uwzględnia zasady prawa kanonicznego i w przepisach wyłącza możliwość przesłuchiwania w charakterze świadka duchownych co do faktów, o których dowiedzieli się $\mathrm{w}$ trakcie spowiedzi. Podmiotem, który może dopuścić się zdrady tajemnicy spowiedzi, jest tylko szafarz sakramentu pokuty i pojednania, gdyż na nim ciąży obowiązek zachowania tajemnicy. Tłumacz lub osoba trzecia słysząca spowiedź przez przypadek zobligowani są do zachowania sekretu spowiedzi.

Tajemnica spowiedzi może zostać naruszona na dwa sposoby: wprost, czyli bezpośrednio, lub ubocznie, czyli pośrednio. Zdrada bez-

77 Benedykt XVI, Przemówienie do uczestników kursu dla spowiedników zorganizowanego przez Penitencjarię Apostolska (11.03.2010 r.), [w:] Kongregacja ds. Duchowieństwa, Kapłan - Szafarz Miłosierdzia Bożego, Tarnów 2011, s. 8.

${ }^{78}$ Jan Paweł II, Adhortacja apostolska Pastorem dabo vobis (25.03.1992), Wrocław 1992, nr 26. 
pośrednia następuje wtedy, gdy szafarz sakramentu pokuty i pojednania, mówiąc o konkretnej osobie, wspomina o fakcie, który zna z jej spowiedzi. Zdrada pośrednia powstaje, gdy spowiednik wyjawia materię spowiedzi, lecz bez ujawniania osoby penitenta, lub odwrotnie. Od sposobu naruszenia tajemnicy spowiedzi, a co za tym idzie ciężkości zdrady tajemnicy sakramentalnej, prawodawca kościelny uzależnił sankcje karne.

Zdrada tajemnicy sakramentalnej jest przestępstwem, za które kanoniczne prawo karne przewiduje odpowiednią sankcję karną. Bezpośrednia zdrada tajemnicy spowiedzi wywołuje sankcje karne w postaci kary ekskomuniki, wiążącej mocą samego prawa, zastrzeżonej Kongregacji Nauki Wiary. Pośrednia zdrada, ze względu na lżejszy charakter przestępstwa, jest zagrożona karą nieokreśloną, stosowną do ciężkości i poczytalności czynu. Czyn karalny polegający na zdradzie tajemnicy spowiedzi przedawnia się po dziesięciu latach od dnia popełnienia przestępstwa.

Streszczenie. Sakrament pokuty i pojednania jako znak pojednania Boga z ludźmi, a sprawowany we wspólnocie Kościoła zobowiązuje szafarza do pokornej i dyspozycyjnej służby wobec osób pragnących doświadczyć Bożego Miłosierdzia, a jednocześnie zobowiązuje szafarza do roztropności, wrażliwości i delikatności, a przede wszystkim do zachowania absolutnej tajemnicy odnośnie do grzechów wyznawanych przez penitenta. Tajemnica spowiedzi jest bezwzględnie nienaruszalna. Wywodzi się ona nie tylko z prawa kościelnego, ale przede wszystkim ma podstawę w prawie Bożym. Stąd też spowiednik został zobligowany do zachowania tajemnicy spowiedzi, która obowiązuje go do końca życia i nie ustaje nawet po śmierci penitenta.

Tajemnica spowiedzi jest chroniona $\mathrm{z}$ jednej strony przez zabranianie pod groźbą kary korzystania $\mathrm{z}$ wiadomości zdobytych $\mathrm{w}$ akcie spowiedzi, następnie przez zakaz przesłuchiwania duchownych jako świadków na okoliczności poznane podczas spowiedzi. Z drugiej strony prawodawstwo świeckie z szacunku dla Kościoła uwzględnia zasady prawa kanonicznego i w przepisach wyłącza możliwość przesłuchiwania w charakterze świadka duchownych co do faktów, o których dowiedzieli się w trakcie spowiedzi. Podmiotem, który może dopuścić się zdrady tajemnicy spowiedzi, jest tylko szafarz sakramentu pokuty i pojednania, gdyż na nim ciąży obowiązek zachowania tajemnicy. Tłumacz lub osoba trzecia słysząca spowiedź przez przypadek zobligowani są do zachowania sekretu spowiedzi.

Tajemnica sakramentalna może zostać naruszona na dwa sposoby: wprost, czyli bezpośrednio, lub ubocznie, czyli pośrednio. Zdrada bezpośrednia następuje wtedy, gdy szafarz sakramentu pokuty i pojednania, mówiąc o konkretnej osobie, wspomina o fakcie, który zna z jej spowiedzi. Zdrada pośrednia powstaje, gdy spowiednik wyjawia materię spowiedzi, lecz bez ujawniania osoby penitenta, lub odwrotnie. Od sposobu naruszenia 
tajemnicy spowiedzi, a co za tym idzie ciężkości zdrady tajemnicy sakramentalnej, prawodawca kościelny uzależnił sankcje karne.

Zdrada tajemnicy sakramentalnej jest przestępstwem, za które kanoniczne prawo karne przewiduje odpowiednią sankcję karną. Bezpośrednia zdrada tajemnicy spowiedzi wywołuje sankcje karne w postaci kary ekskomuniki, wiążącej mocą samego prawa, zastrzeżonej Kongregacji Nauki Wiary. Pośrednia zdrada, ze względu na lżejszy charakter przestępstwa, jest zagrożona karą nieokreśloną, stosowną do ciężkości i poczytalności czynu. Czyn karalny polegający na zdradzie tajemnicy spowiedzi przedawnia się po dziesięciu latach od dnia popełnienia przestępstwa.

Słowa kluczowe: sakrament pokuty i pojednania; tajemnica spowiedzi; zdrada tajemnicy spowiedzi; prawa i obowiązki spowiednika; sankcje karne za zdradę tajemnicy spowiedzi.

Abstract. Betrayal of the seal of confession in the current ecclesiastical legislation. Sacrament of penance as a sign of reconciliation between God and man, and exercised in the Church community obliges the minister to the humble and dispositional services to people wishing to experience the Divine Mercy, but it also requires the minister to prudence, sensitivity and delicacy, and above all to maintain absolute secrecy regarding the sins espoused by the penitent. The secret of confession is absolutely inviolable. It derives not only from ecclesiastical law, but above all has a basis in the law of God. Hence the confessor was obliged to secrecy of confession, which applies it to the end of life and does not stop even after the death of the penitent.

The seal of confession is protected on one side by prohibiting, under penalty of using the knowledge acquired in the act of confession, followed by non-clerics interviewed as a witness on circumstances learned during confession. On the other hand, secular legislation out of respect for the Church's canon law incorporates the principles and provisions excludes the possibility of questioning as a witness of the clergy of the facts about which they learned during confession. The entity, which may allow a betrayal of the seal of confession is the only minister of the sacrament of penance and reconciliation, because he owes a duty of confidentiality. Translator or a third-hearing confession by the case are obliged to secrecy of confession.

The sacramental may be affected in two ways: either directly or indirectly. Direct betrayal occurs when the minister of the sacrament of penance and reconciliation talking about a specific person mentions the fact that familiar with her confession. Indirect betrayal arises when the confessor reveals the matter of confession, but without disclosing the person of the penitent or vice versa. From the way breach of confidentiality of confession, and thus the gravity of the betrayal of the sacramental seal, the legislature church addicted criminal sanctions.

Betrayal of the sacramental seal is a crime for which the canonical penal law provides for appropriate sanctions. Direct betrayal of the seal of confession triggers penalties in the form of a penalty of excommunication latae sententiae reserved to the 
Congregation for the Doctrine of the Faith. Indirect betrayal, because of the lighter nature of the crime is punishable by an unspecified, appropriate to the gravity and sanity action. Punishable acts consisting of betrayal secret confession barred after ten years from the date of the offense.

Keywords: sacrament of penance; seal of confession; betrayal of the seal of confession. rights and obligations of the confessor; penalties for betraying the seal of confession. 
